\title{
Purification and preliminary characterization of a xylanase from Thermomyces lanuginosus strain SS-8
}

\author{
Smriti Shrivastava $\cdot$ Pratyoosh Shukla $\cdot$ \\ Kunal Mukhopadhyay
}

Received: 6 May 2011/Accepted: 8 October 2011 / Published online: 22 October 2011

(c) The Author(s) 2011. This article is published with open access at Springerlink.com

\begin{abstract}
Thermomyces lanuginosus SS-8 was isolated from soil samples that had been collected from near selfheating plant material and its extracellular cellulase-free xylanase purified approximately 160 -fold using ion exchange chromatography and continuous elution electrophoresis. This xylanase was thermoactive (optimum temperature $60{ }^{\circ} \mathrm{C}$ ) at $\mathrm{pH} 6.0$ and had a molecular weight of $23.79 \mathrm{kDa}$ as indicated by SDS-PAGE electrophoresis. The xylanase rapidly hydrolyzed xylan directly to xylose without the production of intermediary xylo-oligosaccharides within $15 \mathrm{~min}$ of incubation under optimum conditions. This trait of rapidly degrading xylan to xylose as a sole end-product could have biotechnological potential in degradation of agro-wastes for bioethanol manufacturing industry.
\end{abstract}

Keywords Bioethanol - Thermomyces lanuginosus . Thermophilic fungi $\cdot$ Xylanase $\cdot$ Xylose

Xylan is the second most abundant heteropolymer in nature (Biely et al. 1985) and is found in close association with cellulose and lignin in plant cell wall. Xylan is formed by a backbone of $\beta$-1,4-D-xylopyranosyl residues, and different substitute groups exist in the side chain. Hence, for complete degradation of these polysaccharides an enzymatic complex comprising xylanases $(\beta-1,4-\mathrm{D}-\mathrm{xylan}$ xylanohydrolase, EC 3.2.1.8) and $\beta$-xylosidases ( $\beta$-1,4-D-xylan xylohydrolase, EC 3.2.1.37) are required. Xylanases cleave

S. Shrivastava $\cdot$ P. Shukla $(\varangle) \cdot$ K. Mukhopadhyay Enzyme Technology Laboratory, Department of Biotechnology, Birla Institute of Technology (Deemed University), Mesra, Ranchi, Jharkhand, India e-mail: pshukla@bitmesra.ac.in; pratyoosh.shukla@gmail.com internal xylosidic linkages producing xylo-oligosaccharides, while $\beta$-xylosidases hydrolyze the oligosaccharides releasing xylose (Sunna and Antranikian 1997). Xylotriose has been reported to be the smallest xylo-oligosaccharide released during hydrolysis of xylan by xylanases (Ryan et al. 2003). As resistance to thermal inactivation in many industrial applications has become a desirable property of enzymes Singh et al. 2000), there has been an increasing focus on thermostable xylanases. Most of the current applications of thermostable xylanases are in pulp and paper industries, in which these enzymes are active at high temperature and alkaline $\mathrm{pH}$ (Beg et al. 2001). Thermostable xylanases have potential applications in fruit and vegetable processing, brewing, wine production, baking, animal feeds, starch, textiles industries, etc. (Beg et al. 2001; Viikari et al. 1994; Subramaniyan and Prema 2002). In addition, xylanases have also been found to play important roles in plant tissues in fruit softening, seed germination and plant defense systems (Prade 1995; Deising and Mendgen 1991). Cellulase-free xylanases have applications in textile industries. Several strains of the Ascomycetes fungi, Thermomyces lanuginosus (formerly known as Humicola lanuginose) are reported to produce high levels of cellulase-free thermostable $\beta$-xylanases belonging to family 11 of glycosyl hydrolases (Singh et al. 2003; Gaffney et al. 2009; Shrivastava et al. 2009). In the present study a thermophilic fungal strain SS-8 was identified as $T$. lanuginosus based on the sequencing of its GenBank accession number: GQ469970. Strain SS-8 was found to produce a novel extracellular xylanase whose characteristics are communicated here.

Soil samples adjacent to self-heating plant debris and wastes were collected from various locations in Jharkhand State, India. Fungi were isolated and screened for extracellular xylanase activity on Potato Dextrose Agar (PDA) 
plates containing $0.15 \%$ Remazol brilliant blue xylan (RBB-xylan, Sigma-Aldrich Chemei GmbH, Steinheim, Germany). Colonies showing clear zone of degradation of RBB-xylan were isolated and screened to select and prioritize the highest xylanase producers. For this the fungal isolates were grown on a production medium. Production medium ( $\mathrm{pH}$ 6.5) contained yeast extract (Himedia, India) $1.5 \%, \mathrm{KH}_{2} \mathrm{PO}_{4}$ (Himedia, India) $0.5 \%$ and $1.5 \%$ wheat bran (obtained from a local farmhouse). The fungal isolates were inoculated into production medium followed by incubation at $50{ }^{\circ} \mathrm{C}$ for 5 days using submerged fermentation. Xylanase activity was assayed using $2 \%(\mathrm{w} / \mathrm{v})$ OSX (Oat Spelts Xylan) in $50 \mathrm{mM}$ sodium acetate buffer, $\mathrm{pH} 5.3$ at $50{ }^{\circ} \mathrm{C}$ (Biely et al. 1985). The reducing sugars liberated were quantified by the dinitrosalicylic acid (DNS) method (Miller 1959) using xylose (SigmaUltra, Sigma-Aldrich, St. Louis, MO, USA) as the standard. The amount of reducing sugars present was measured at $540 \mathrm{~nm}$ in a UVVis spectrophotometer (PerkinElmer Life and Analytical Sciences, Inc, Waltham, MA, USA). One unit of xylanase activity is defined as the amount of enzyme required to release $1 \mu \mathrm{mol}$ of reducing sugar equivalent to xylose per min at $50{ }^{\circ} \mathrm{C}, \mathrm{pH}$ 5.3. Twenty-five fungal strains were isolated from the soil samples of which 11 were extracellular xylanase producers. Strain SS-8 was observed to be the highest xylanase producer among all the 11 isolates and was therefore selected for further studies.

The morphology of strain SS-8 was determined by staining with lactophenol blue (Leck 1999) and calcoflour (Hageage and Harrington 1984). The cells were filamentous with septate hyphae, white in color, which simultaneously turned to yellow and then brown as they matured. They possessed aleurioconidia with a diameter range of $0.75-11 \mu \mathrm{m}$ depending on stage of maturity. The 18S rDNA Internal Transcribed Spacer (ITS) region was sequenced commercially by Bangalore Genei, Bangalore, India. The nucleotide sequence (LENGTH) was analyzed using the BLASTn search program (http://blast.ncbi.nlm.nih.gov/) against the Genbank nucleotide (nr/nt) collection. BLAST analysis suggested that strain SS-8 was a strain of T. lanuginosus.

Strain SS-8 was cultured in production medium as described above and the xylanase was purified. For this, after 5 days incubation, the broth was clarified by centrifugation and the supernatant filtered through a $0.45 \mu \mathrm{m}$ hydrophilic polyamide (HNWP) nylon membrane filter (Millipore Ireland B.V., Carrigtwohill, Ireland) using a vacuum manifold. The filtrate was purified using an anion exchange column (HiTrap Q FF 5 ml, GE Healthcare BioSciences AB, Uppsala, Sweden) fitted to a low pressure chromatography system (ÄKTA Prime, GE Healthcare BioSciences AB, Uppsala, Sweden) that had been previously equilibrated with $25 \mathrm{mM}$ Tris- $\mathrm{HCl}$ buffer $(\mathrm{pH}$ 7.5). The analyte was eluted in 2.5-ml fractions with a linear gradient of $0-1 \mathrm{M} \mathrm{NaCl}$ in $25 \mathrm{MM}$ Tris- $\mathrm{HCl}$ buffer $(\mathrm{pH} 7.5)$ at a flow rate $1 \mathrm{ml} \mathrm{min}^{-1}$ ). Fractions containing xylanase were identified using xylanase assays, pooled and subjected to continuous elution electrophoresis (CEE). For this, a Mini Prep Cell (Bio-Rad Laboratories, Hercules, CA, USA) containing $15 \%$ native polyacrylamide gel was used. An Econo System low pressure chromatography components, including peristaltic pump and fraction collector (Bio-Rad Laboratories, Hercules, CA, USA) were used for elution of the protein fractions with power supplied at $300 \mathrm{~V}$ and flow rate of $100 \mu \mathrm{min}^{-1}$. The elute was passed through an Amicon 10000 MOCO Ultra 50 centrifugal filter (Millipore Corporation, Bedford, MA) to remove contaminants and concentrate the enzyme. Samples were removed during purification and assayed for xylanase and cellulase activities and for protein concentration. Protein concentration was determined by the method of Bradford (1976) using bovine serum albumin as standard. Cellulase activity was assayed as described for xylanase assay except that carboxy methyl cellulose (CMC) was substituted instead of xylan. Specific activity is expressed as unit per milligram of protein. Molecular weight of the purified xylanase was determined using SDS-PAGE gel electrophoresis followed by staining the gel with Deep Purple (GE Healthcare BioSciences Ltd., Buckinghamshire, England) as recommended by the manufacturer. Low molecular weight protein markers (PMW-L) from Bangalore Genei, Bangalore, India, were used as standards. The gel was scanned at $532 \mathrm{~nm}$ on a Typhoon 9410 multimode image analyzer (GE Healthcare, Sunnyvale, CA, USA) and the molecular weight was determined using ImageQuant TL 1D gel analysis software v2003.3 (GE Healthcare Bio-Sciences Ltd., Buckinghamshire, England) against the protein markers.

Data on the purification of the xylanase at various steps is summarized in Table 1. Anion exchange chromatography using HiTrap Q showed a single peak with xylanase activity (Fig. 1). The native PAGE on Mini Prep Cell (peak A, Fig. 2) shows the enzyme purified to homogeneity. A 166-fold purification was achieved from the culture filtrate. The xylanase was found to be cellulase-free at all stages of purification. A single protein band was observed on a $18 \%$ SDS-PAGE, suggesting that the xylanase was made of a single polypeptide chain with a molecular mass of $23.79 \mathrm{kDa}$ as estimated by using the ImageQuant $1 \mathrm{D}$ gel analysis software (Fig. 3). The optimum temperature for the enzyme at pH 6.0 was determined to be $60{ }^{\circ} \mathrm{C}$ (Fig. 4).

The end-products of xylanase hydrolysis were determined by thin layer chromatography (TLC). For this, $3 \mathrm{ml}$ of the xylan solution (10 mg OSX in $5.0 \mathrm{ml} 50 \mathrm{mM}$ sodium acetate buffer, $\mathrm{pH}$ 6.0) was incubated with 8 Units of purified enzyme at $60{ }^{\circ} \mathrm{C}$. $0.3-\mathrm{ml}$ aliquots were retrieved at intervals ranging from 0.25 to $72 \mathrm{~h}$. Assay reactions 
Table 1 Summary of purification steps of xylanase from $T$. lanuginosus SS-8 grown on wheat bran as substrate

$C E E$ continuous elution electrophoresis

\begin{tabular}{lccccc}
\hline Purification steps & $\begin{array}{l}\text { Total proteins } \\
(\mathrm{mg})\end{array}$ & $\begin{array}{l}\text { Total activity } \\
(\mathrm{U})\end{array}$ & $\begin{array}{l}\text { Specific activity } \\
\left(\mathrm{U} \mathrm{mg} \mathrm{mg}^{-1}\right)\end{array}$ & $\begin{array}{l}\text { Purification } \\
(\text { fold })\end{array}$ & $\begin{array}{l}\text { Yield } \\
(\%)\end{array}$ \\
\hline Crude culture filtrate & $1,544.4$ & 6,800 & 4.40 & 1 & 100 \\
Ultrafiltration retentate & 34.18 & $1,382.4$ & 40.44 & 9.2 & 20.3 \\
HiTrap Q FF & 3.37 & 338.4 & 100.45 & 22.8 & 4.98 \\
CEE & 0.15 & 109.3 & 728.73 & 165.5 & 1.61 \\
\hline
\end{tabular}

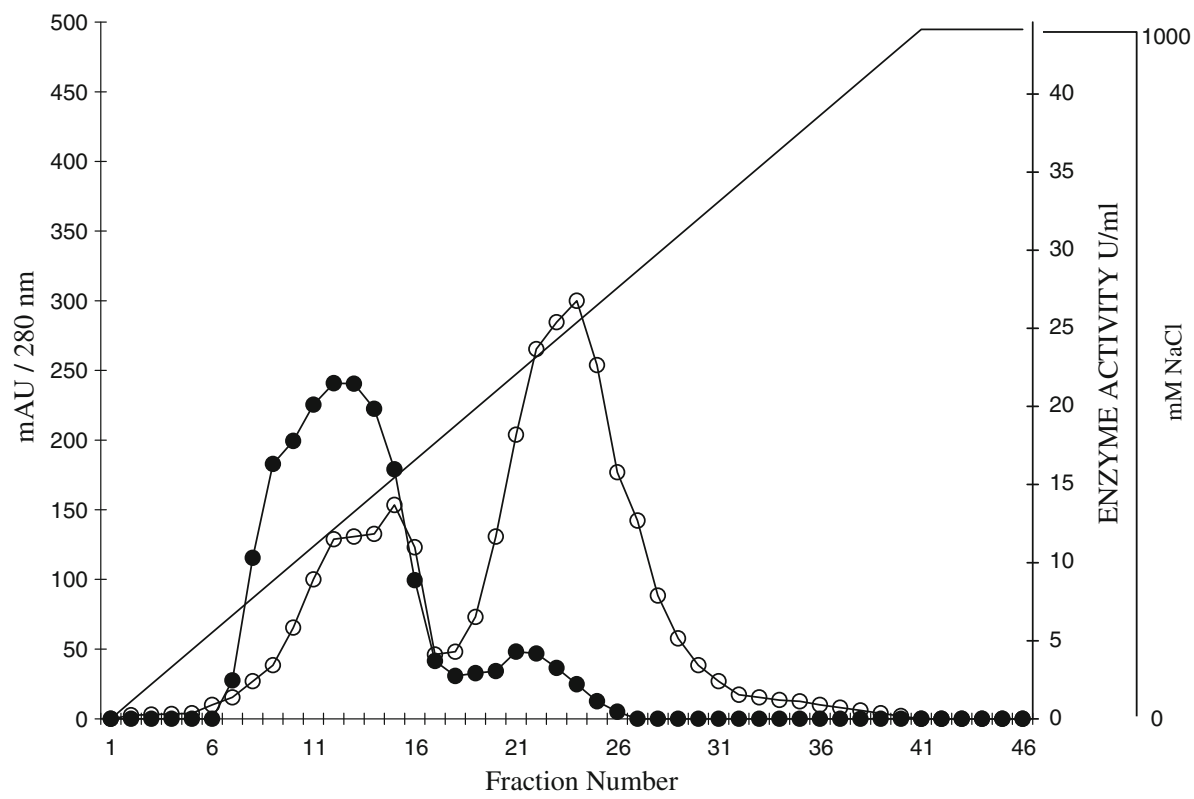

Fig. 1 Elution profile of anio exchange chromatography of xylanase on HiTrap Q FF. Xylanase activity (filled circles); total protein (empty circles absorbance at $280 \mathrm{~nm}$; $\mathrm{NaCl}$ (straight line)

Fig. 2 Elution profile of continuous elution electrophoresis for purification of xylanase on native polyacrylamide gel (15\%). Peak $A$ represents purified xylanase. Xylanase activity (filled circle) and total protein (empty circle absorbance at $280 \mathrm{~nm}$ )

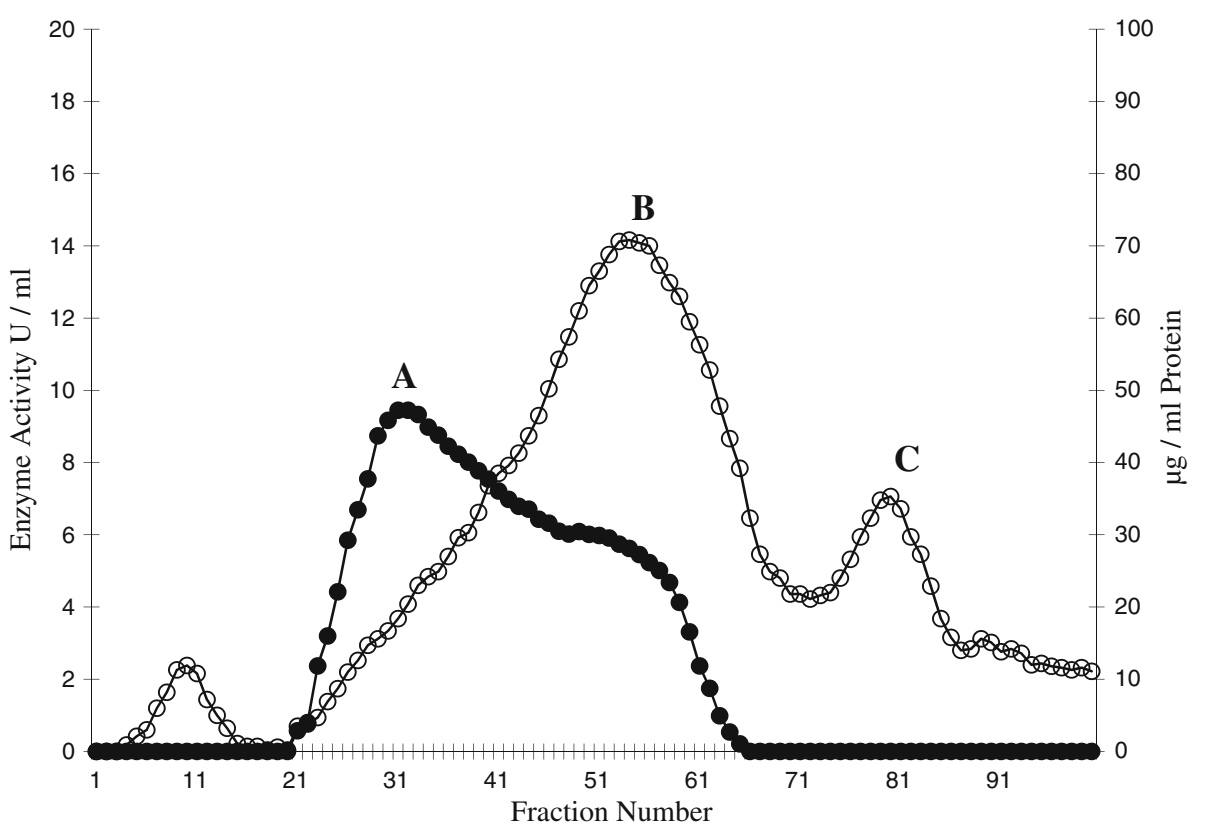

without added enzyme were used as controls. $2 \mu \mathrm{l}$ were spotted on Silica gel/TLC-cards, DC-Alufolien-Kieselgel (Fluka, Sigma-Aldrich, Seelz, Germany) and the hydrolysis products analyzed according to the method of Jiang et al. (2004). Aliquots of $0.3 \mathrm{ml}$ were taken after $0.25,0.5,1,3$, $6,12,24,48$ and $72 \mathrm{~h}$ of incubation and concentrated to 


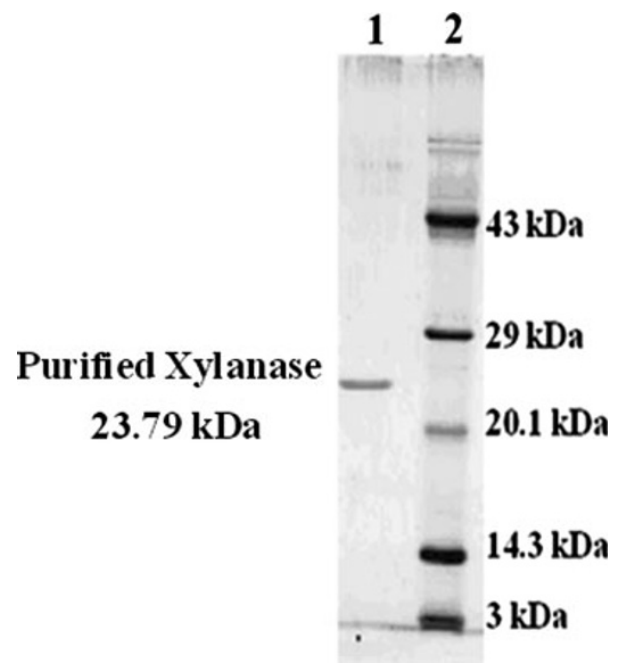

Fig. 3 Molecular weight of purified xylanase from T. lanuginosus SS-8. SDS-PAGE (18\%): lane 1 purified xylanase, lane 2 PMW-L marker

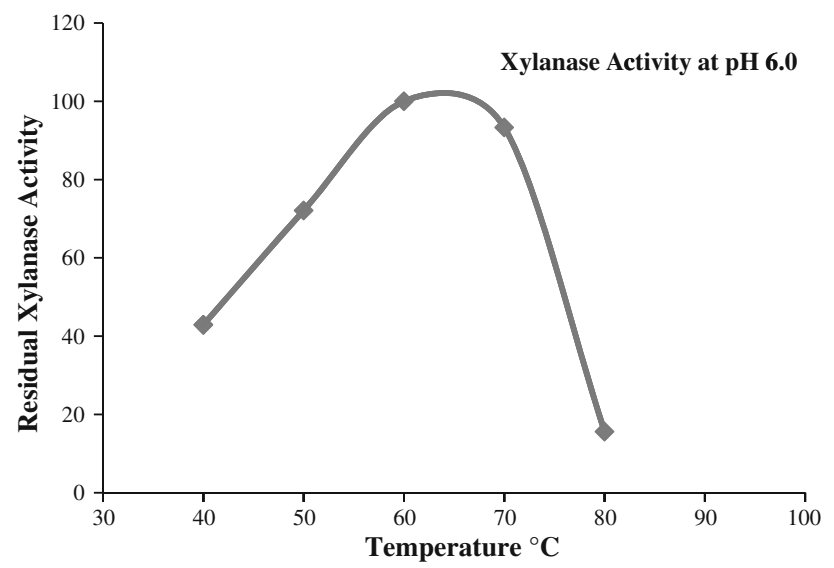

Fig. 4 Optimum temperature of activity of xylanase from strain SS-8 at $\mathrm{pH} 6.0$

$0.2 \mathrm{ml}$. Blanks (1 and $72 \mathrm{~h})$ containing xylan in buffer without xylanase were also incubated at $60{ }^{\circ} \mathrm{C}$. The endproducts of xylan degradation by the purified xylanase from incubations at different time intervals always showed the presence of xylose and no xylo-oligosaccharide intermediates were detected. Most xylanases reported to date (Ryan et al. 2003; Li et al. 2005; Sapre et al. 2005; Khandeparkar and Bhosle 2006; Li et al. 2006; Knob and Carmona 2009; Jiang et al. 2010; Hung et al. 2011) produce various xylo-oligosaccharides upon hydrolysis of xylan which are further hydrolyzed to xylose by xylosidases (Whistler and Masek 1955; Kulkarni et al. 1999). Even multifunctional xylanases (Ashabil and Burhan 2009; Xue et al. 2009) containing different combinations of xylan-degrading enzymes are unable to directly produce xylose as the end-product. This makes the xylanase from $T$. lanuginosus SS-8 unique amongst xylanases. The purified

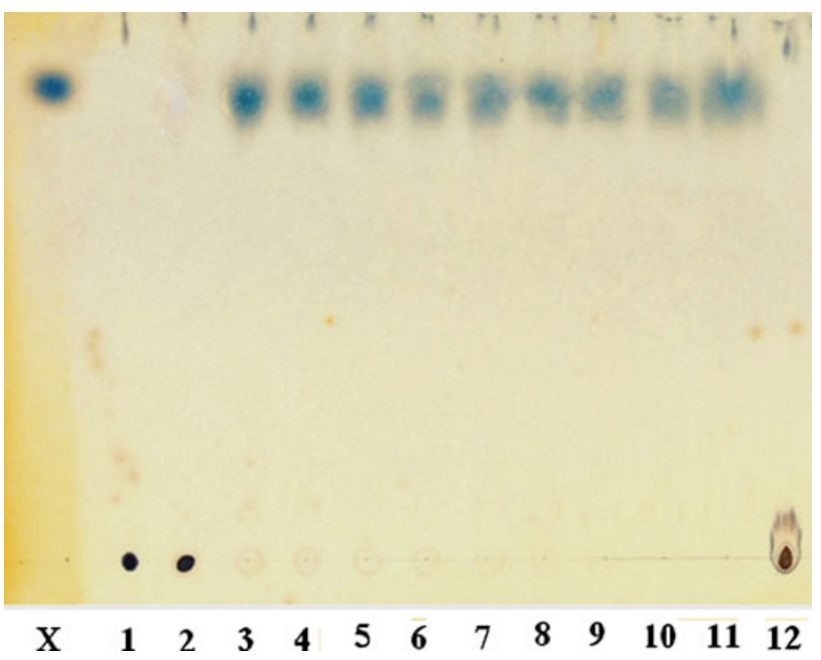

Fig. 5 Analysis of hydrolysis product of oat spelts xylan degraded by xylanase from $T$. lanuginosus SS-8. Lane $X$ xylose standard, lane 1 xylan $0 \mathrm{~h}$ blank, lane $20 \mathrm{~h}$ hydrolysis, lane $30.25 \mathrm{~h}$ hydrolysis, lane $40.5 \mathrm{~h}$ hydrolysis, lane $51 \mathrm{~h}$ hydrolysis, lane $63 \mathrm{~h}$ hydrolysis, lane 7 $6 \mathrm{~h}$ hydrolysis, lane $812 \mathrm{~h}$ hydrolysis, lane $924 \mathrm{~h}$ hydrolysis, lane 10 $48 \mathrm{~h}$ hydrolysis, lane $1172 \mathrm{~h}$ hydrolysis, lane 12 xylan $1 \mathrm{~h}$ blank

xylanase was also found to be fast acting as it completely hydrolyzed xylan to xylose within 15 min of incubation at $60{ }^{\circ} \mathrm{C}$ (Fig. 5). The fast acting, xylose producing, thermostable xylanase from $T$. lanuginosus SS-8 may have potential in degrading xylan-rich agro-wastes to ethanol and further research is currently underway in our laboratory.

Acknowledgments The authors gratefully acknowledge the Department of Agriculture, Government of Jharkhand, for providing infrastructure development fund to Birla Institute of Technology, Mesra, Ranchi. Smriti Shrivastava is thankful to CSIR for Senior Research Fellowship (Grant No: 09/554(0017)/2008 EMR-I).

\section{Conflict of interest None.}

Open Access This article is distributed under the terms of the Creative Commons Attribution License which permits any use, distribution and reproduction in any medium, provided the original author(s) and source are credited.

\section{References}

Ashabil A, Burhan A (2009) Production and characterization of multifunctional endoxylanase by Bacillus sp. X13. Turk J Biol 33:231-237

Beg QK, Kapoor M, Mahajan L, Hoondal GS (2001) Microbial xylanases and their industrial applications: a review. Appl Microbiol Biotechnol 56:326-338

Biely P et al (1985) Microbial xylanolytic systems. Trends Biotechnol 3:286-290

Bradford MM (1976) A rapid and sensitive method for quantitation of microgram quantities of protein utilizing the principle of protein-dye binding. Anal Biochem 72:248-254 
Deising H, Mendgen K (1991) Developmental control of enzyme production and cell wall modification in rust fungi, and defense reactions of the host plant. In: Stahl U, Tudzynski P (eds) Molecular biology of filamentous fungi. $\mathrm{VCH}$, Weinham, pp 27-44

Gaffney M, Carberry S, Doyle S, Murphy R (2009) Purification and characterisation of a xylanase from Thermomyces lanuginosus and its functional expression by Pichia pastoris. Enzyme Microb Technol 45:348-354

Hageage GJ, Harrington BJ (1984) Use of calcofluor white in clinical mycology. Lab Med 15:109-112

Hung KS, Liu SM, Fang TY, Tzou WS, Lin FP, Sun KH, Tang SJ (2011) Characterization of a salt-tolerant xylanase from Thermoanaerobacterium saccharolyticum NTOU1. Biotechnol Lett. doi:10.1007/s10529-011-0579-7

Jiang ZQ, Deng W, Zhu YP, Li LT, Sheng YJ, Hayashi K (2004) The recombinant xylanase $\mathrm{B}$ of Thermotoga maritima is highly xylan specific and produces exclusively xylobiose from xylans, a unique character of industrial applications. J Mol Cat 27:207-213

Jiang Z, Cong Q, Yan Q, Kumar N, Dub X (2010) Characterisation of a thermostable xylanase from Chaetomium sp. and its application in Chinese steamed bread. Food Chem 120:457-462

Khandeparkar RDS, Bhosle NB (2006) Isolation, purification and characterization of the xylanase produced by Arthrobacter sp. MTCC 5214 when grown in solid state fermentation. Enzyme Microb Technol 39:732-742

Knob A, Carmona EC (2009) Purification and characterization of two extracellular xylanases from Penicillium sclerotiorum: a novel acidophilic xylanase. Appl Biochem Biotechnol 9:8731-8738

Kulkarni N, Shendye A, Rao M (1999) Molecular and biotechnological aspects of xylans. FEMS Microbiol Rev 23:411-456

Leck A (1999) Preparation of lactophenol cotton blue slide mounts. Community Eye Health 30:12-24

Li XT, Jiang ZQ, Li LT, Yang SQ, Feng WY, Fan JY, Kusakabe I (2005) Characterization of a cellulase-free, neutral xylanase from Thermomyces lanuginosus CBS 288.54 and its biobleaching effect on wheat straw pulp. Bioresour Technol 96:13701379
Li L, Tian H, Cheng Y, Jiang Z, Yang S (2006) Purification and characterization of a thermostable cellulase-free xylanase from the newly isolated Paecilomyces thermophila. Enzyme Microb Technol 38:780-787

Miller GH (1959) Use of dinitrosalicylic acid reagent for determination of reducing sugar. Anal Chem 31:426-429

Prade RA (1995) Xylanases: from biology to biotechnology. Biotechnol Genet Eng Rev 13:101-131

Ryan SE, Nolan K, Thompson R, Gubitz GM, Savage AV, Tuohy MG (2003) Purification and characterization of a new low molecular weight endoxylanase from Penicillium capsulatum. Enzyme Microb Technol 33:775-785

Sapre MP, Jha H, Patil MB (2005) Purification and characterization of a thermoalkalophilic xylanase from Bacillus sp. World J Microbiol Biotechnol 21:649-654

Shrivastava S, Poddar R, Shukla P, Mukhopadhyay K (2009) Study of codon bias perspective of fungal xylanase gene by multivariate analysis. Bioinformation 3:425-429

Singh S, Pillay B, Prior BA (2000) Thermal stability of $\beta$-xylanases produced by different Thermomyces lanuginosus strains. Enzyme Microb Technol 26:502-508

Singh S, Mandala AM, Prior BA (2003) Thermomyces lanuginosus: properties of strains and their hemicellulases. FEMS Microbiol Rev 27:3-16

Subramaniyan S, Prema P (2002) Biotechnology of microbial xylanases, enzymology, molecular biology, and application. Crit Rev Biotechnol 22:33-64

Sunna A, Antranikian G (1997) Xylanolytic enzymes from fungi and bacteria. Crit Rev Biotechnol 17:39-67

Viikari L, Kantelinen A, Sundquist J, Linko M (1994) Xylanases in bleaching: from idea to the industry. FEMS Microbiol Rev 13:335-350

Whistler R, Masek E (1955) Enzymatic hydrolysis of xylan. J Am Chem Soc 77:1241-1243

Xue Y, Peng J, Wang R, Song X (2009) Construction of the trifunctional enzyme associating the Thermoanaerobacter ethanolicus xylosidase-arabinosidase with the Thermomyces lanuginosus xylanase for degradation of arabinoxylan. Enzyme Microb Technol 45:22-27 